\title{
Zasada nieodpowiedzialności monarchy i kontrasygnaty jego aktów. Przykład włoski
}

I. Uwagi wprowadzające. Kontrasygnata aktów głowy państwa stanowi ważną instytucję ustrojową. Jej wprowadzenie ma istotny wpływ na pozycję tak monarchy, jak i obieralnego prezydenta. Jednocześnie jest to pojęcie, co do którego w piśmiennictwie - także współczesnym - występuje szereg nieporozumień. Zbyt często kontrasygnacie przypisuje się inny sens i rolę niż te, które ma w istocie. Dlatego warto sięgnąć do przeszłości, by przypomnieć genezę i kształtowanie się zasady współpodpisu ${ }^{1}$ oraz przyjrzeć się jej postrzeganiu w dawnej literaturze przedmiotu. W przypadku monarchii wymóg kontrasygnaty jest tak ściśle powiązany z zasadą nieodpowiedzialności głowy państwa, że obie te reguły ustrojowe zdecydowaliśmy się przedstawić łącznie, tym bardziej że zazwyczaj tak opisywano je w niżej przywoływanej literaturze przedmiotu.

Ciekawym polem badań nad instytucją kontrasygnaty jest Królestwo Włoch. We włoskiej ustawie zasadniczej przyjęto rozwiązanie nieco odbiegające od zapisanych w innych konstytucjach, zaś w pracach różnych autorów odnajdujemy interesujące i urozmaicone wypowiedzi na temat nieodpowiedzialności władcy i kontrasygnaty jego aktów. Dlatego zajmujemy się z jednej strony treścią przepisów ustawy zasadniczej, a z drugiej - ich interpretacją dokonywaną przez dawnych włoskich konstytucjonalistów. Prezentując rozwiązania przyjmowane w Italii, sięgamy w pierwszej kolejności do konstytucji państw Półwyspu Apenińskiego wydawanych w latach Wiosny Ludów (są to akty rzadko dostrzegane przez polskich autorów). Zajmujemy się kontrasygnatą we Włoszech przed rokiem 1922, czyli przed marszem na Rzym, który przyniósł radykalną zmianę ustroju. Funkcjonowanie współpodpisu po prze-

${ }^{1}$ We współczesnym polskim piśmiennictwie pojęcia kontrasygnaty i współpodpisu traktowane są jako synonimy - Z. Witkowski, Kontrasygnata, [w:] B. Hołyst (red.), Wielka encyklopedia prawa, Warszawa 2005, s. 360; A. Frankiewicz, Kontrasygnata aktów urzędowych prezydenta RP, Kraków 2004, s. 11-12, 177-178; A. Rakowska, Kontrasygnata aktów głowy państwa w wybranych państwach europejskich, Torun 2009, s. 12. 
jęciu władzy przez faszystów warto uczynić przedmiotem odrębnych badań, które dotykałyby roli króla w okresie dyktatury Mussoliniego.

Uznaliśmy za wskazane, by przed omówieniem rozwiązań przyjętych w Królestwie Włoch, przedstawić te, które wcześniej lub równocześnie obowiązywały w innych państwach europejskich. Pozwala to na porównanie regulacji przyjętej we włoskiej ustawie zasadniczej z tymi, które wprowadzono w innych krajach.

Pojęciem kontrasygnaty (współpodpisu) we współczesnym polskim piśmiennictwie zajmujemy się tylko dla zasygnalizowania występujących problemów, wątpliwości i - naszym zdaniem - mitów. Szersze omawianie poglądów na temat istoty kontrasygnaty obecnych w dawniejszej i nowszej polskiej literaturze przedmiotu wykraczałoby poza ramy tej publikacji.

\section{Pojęcie i istota kontrasygnaty.}

1. Prezentowane współcześnie definicje kontrasygnaty za wspólny mianownik mają eksponowanie, że stanowi ona podpis (współpodpis) złożony przez członka rządu na akcie urzędowym głowy państwa, konieczny dla jego ważności².

2. Za błędny uznajemy pogląd (przedstawiony niestety również w podręcznikach akademickich), że istotą kontrasygnaty jest ,przejęcie” odpowiedzialności przez ministra, czy też wprowadzeniem wymogu współpodpisu nie była wyraźnie sformułowana zasada odpowiedzialności prawnej (a tym bardziej politycznej) monarchy ${ }^{3}$, to na ministra nie było czego ,przenosić” ani czego „przejmować”. Gdy zaś głową państwa jest prawnie odpowiedzialny prezydent, to zatwierdzenie jego aktu przez ministra nie zwalnia go z odpowiedzialności, a skutkować może jedynie współodpowiedzialnością za złamanie prawa (więc i w takim przypadku nic nie jest ,przejmowane” ani ,przenoszone"). Za to za poprawne uznajemy posługiwanie się pojęciami takimi jak „przyjmowanie” lub „branie” odpowiedzialności, nie zawierają one bowiem sugestii, że przez fakt złożenia przez ministra podpisu głowa państwa zostaje uwolniona od odpowiedzialności, którą miałaby ponosić4.

3. Istota kontrasygnaty wynika z zasady podziału - czyli dekoncentracji - władzy publicznej, to jest z przekonania, że żaden z organów nie powinien skupiać w swych rękach zbyt szerokich kompetencji. Dotyczyło to w szczególności panujących, dlatego w dziewiętnastowiecznych monarchiach konstytucyjnych za oczywistą uznawano regułę, że nieodpowiedzialny król nie może

${ }^{2}$ M. Kruk, Historyczno-porównawcze aspekty kontrasygnaty aktów prezydenta, „Biuletyn Rady Legislacyjnej” 1994, nr 1, s. 245; J. Braciak, Kontrasygnata, [w:] U. Kalina-Prasznic (red.), Leksykon prawniczy, Wrocław 1999, s. 166-167; Z. Witkowski, Kontrasygnata, s. 360; R. Mojak, Prezydent Rzeczypospolitej Polskiej, [w:] W. Skrzydło (red.), Polskie prawo konstytucyjne, Lublin 2003, s. 307; A. Frankiewicz, op. cit., s. 11-12, 173-177; A. Rakowska, op. cit., s. 11-16.

${ }^{3}$ Choć znamy przykłady osądzenia, skazania i pozbawienia życia władcy, jak w przypadku angielskiego Karola II czy francuskiego Ludwika XVI.

${ }^{4}$ Por. art. 144 ust. 2 konstytucji Rzeczypospolitej Polskiej z 2 kwietnia 1997 r. 
działać sam. Nie chodziło więc o zdjęcie z władcy odpowiedzialności (której nie ponosił), ale o pozbawienie go samodzielności, czyli odebranie mu realnej władzy. Naszym zdaniem sformułowania o ,przejmowaniu odpowiedzialności" umieszczane w ustawach zasadniczych stanowiły jedynie nieuprawniony skrót myślowy, a ich użycie miało na celu ochronę autorytetu władcy i zamaskowanie rzeczywistej treści przyjmowanych rozwiązań prawnych.

4. Na marginesie wskażmy kolejne uproszczenie: przedstawianie kontrasygnaty jako zatwierdzania aktów głowy państwa przez jednego z ministrów. W konstytucji francuskiej czytamy, że w określonych warunkach akty premiera są kontrasygnowane przez ministrów odpowiedzialnych za ich wykonanie (art. 22 konstytucji Republiki Francuskiej z 4 października 1958 r. ${ }^{5}$ ).

\section{Nieopowiedzialność monarchy i kontrasygnata jego aktów w eu- ropejskich ustawach zasadniczych do I wojny światowej.}

1. Za ojczyznę kontrasygnaty uchodzi Anglia ${ }^{6}$. Przed Chwalebną Rewolucją (1688 r.) ustrojowym aksjomatem było założenie, że król nie może czynić źle i - co do zasady - nie ponosił odpowiedzialności prawnej ani politycznej (choć wyjątek uczyniono dla Karola II). Ministrowie (członkowie kształtującego się wówczas gabinetu) politycznie odpowiadali jedynie przed władcą, a prawnie przed parlamentem (w trybie impeachment lub act of attainder). W XVIII w. stopniowo kształtowała się zasada politycznej odpowiedzialności gabinetu przed parlamentem. Podpis ministra pod aktem monarchy, który wcześniej stanowił jedynie potwierdzenie autentyczności dokumentu, stawał się formalnie zgodą na działanie panującego, której minister mógł odmówić. W praktyce jednak kolejność była odwrotna: ministrowie przedkładali władcy akty przez siebie przygotowane i podpisane, czyli zawczasu kontrasygnowane. Angielska kontrasygnata kształtowała się jako ważny element przejmowania przez gabinet uprawnień panującego, nie zaś w związku z poszukiwaniem podmiotów, które mogłyby ponosić prawną lub polityczną odpowiedzialność za politykę państwa ${ }^{7}$.

2. Nieodpowiedzialność panującego i zasadę współpodpisu odnajdujemy w europejskich konstytucjach wydanych jeszcze w wieku XVIII. W polskiej konstytucji majowej (art. VII - Król, władza wykonawcza) czytamy, że „osoba króla jest święta i bezpieczna od wszystkiego: nic sam przez się nieczyniący, za nic w odpowiedzi narodowi być nie może". Dalej odnajdujemy postanowienie, że rezolucje Straży Praw podpisywane miały być przez władcę, ale każda z nich ,powinna jednak być podpisana także przez jednego z ministrów zasiadających w Straży, i tak podpisana do posłuszeństwa wiązać będzie".

\footnotetext{
${ }^{5}$ Tekst w: M.J. Ptak, M. Kinstler, Powszechna historia państwa i prawa. Wybór tekstów źródlowych, Wrocław 1999, s. 118-126.

${ }^{6}$ Zob. dla przykładu - Z. Witkowski, Kontrasygnata, s. 360; A. Rakowska, op. cit., s. 6 i 16.

${ }^{7}$ A. Rakowska, op. cit., s. 16-22. Zob. też: A. Frankiewicz, op. cit., s. 19-29.
} 
We francuskiej konstytucji z 3 września $1791 \mathrm{r}^{8}{ }^{2}$ zadeklarowano, że „osoba króla jest nietykalna i święta" - inviolable et sacrée (tytuł III, rozdział II, sekcja I, art. 1). W tym samym rozdziale (sekcja IV - art. 4) zapisano zasadę, że żaden królewski rozkaz nie mógł być wykonany, o ile nie był podpisany przez władcę i kontrasygnowany przez ministra lub kierownika departamentu.

3. Na rozwój europejskiego konstytucjonalizmu istotny wpływ miała francuska karta konstytucyjna z 4 czerwca 1814 r., oktrojowana przez Ludwika XVIII; kolejna ustawa zasadnicza z 14 sierpnia 1830 r. stanowiła jedynie jej modyfikację. Zgodnie z art. 13 zd. 1 karty z 1814 r. ${ }^{9}$ osoba władcy była „nietykalna i święta” (inviolable et sacrée), a odpowiedzialni mieli być królewscy ministrowie. W ustawie zasadniczej o kontrasygnacie aktów władcy nie było mowy (również po 1830 r.), jednak praktyka ją stosowała ${ }^{10}$.

W uchwalonej 4 listopada 1848 r. konstytucji II Republiki ${ }^{11}$ wprowadzono obowiązek kontrasygnaty wszystkich aktów prezydenta, z wyłączeniem tych, które miały za przedmiot powołanie lub odwołanie ministra (art. 67). Takie określenie prerogatyw głowy państwa było wyjątkiem na tle rozwiązań przyjmowanych w dziewiętnastowiecznych ustawach zasadniczych.

Interesującej zmiany konstytucji imperialnej dokonano w drodze sénatus-consulte z 21 maja 1870 r. ${ }^{12}$, wydanej na podstawie plebiscytu przeprowadzonego 20 kwietnia 1870 r. Ze znowelizowanego art. 13 ustawy zasadniczej wynikało, że cesarz jest „odpowiedzialny przed ludem francuskim”. Jednak wobec nieokreślenia trybu pociągania do odpowiedzialności, przepis ten stanowił jedynie figurę retoryczną. Z kolei we francuskiej ustawie konstytucyjnej z 31 sierpnia $1871 \mathrm{r}^{13}$ postanowiono, że głową państwa jest prezydent republiki (art. 1), odpowiedzialny przed Zgromadzeniem (art. 3). Zgodnie $\mathrm{z}$ art. 2 zd. 7 dla ważności wszystkich aktów prezydenta wprowadzono wymóg ministerialnej kontrasygnaty.

W III Republice głową państwa był prezydent, ponoszący odpowiedzialność prawną za zdradę główną - art. 6 zd. 2 ustawy o organizacji władz publicznych z 25 lutego 1875 r. ${ }^{14}$ Każdy jego akt powinien być kontrasygnowany przez ministra (art. 3 zd. 7 przywołanej ustawy).

4. $\mathrm{W}$ art. 63 konstytucji Belgii z 7 lutego $1831 \mathrm{rr}^{15}$ zapisano, że osoba królewska jest nietykalna (inviolable), a odpowiedzialni są jego ministrowie.

${ }^{8} \mathrm{http} / / /$ mjp.univ-perp.fr/france/co1791.htm - stan na 1 maja $2013 \mathrm{r}$.

${ }^{9} \mathrm{http} / / /$ mjp.univ-perp.fr/france/co1814.htm - stan na 1 maja $2013 \mathrm{r}$.

${ }^{10}$ A. Frankiewicz, op. cit., s. 31.

${ }^{11} \mathrm{http} / / / \mathrm{mjp}$.univ-perp.fr/france/co1848.htm - stan na 1 maja $2013 \mathrm{r}$.

${ }^{12} \mathrm{http} / / / \mathrm{mjp}$.univ-perp.fr/france/co1870.htm - stan na 1 maja $2013 \mathrm{r}$.

${ }^{13} \mathrm{http} / / / \mathrm{mjp}$.univ-perp.fr/france/co1871r.htm\#31/8/71 - stan na 1 maja $2013 \mathrm{r}$.

${ }^{14}$ Tekst ustaw konstytucyjnych III Republiki w: M. Podgórska, M. Rakowski, Powszechna historia państwa i prawa. Wybór tekstów źródlowych, Łódź 2001, s. 67-69.

${ }^{15}$ Tekst konstytucji w: Constitution belge du 7 février 1831 modifiée les 7 septembre 1893, 15 novembre 1920, 7 février, 24 aout et 15 octobre 1921, Bruxelles 1952; De belgische grondwet van 
Pozycję władcy ograniczono wynikającym z art. 64 obowiązkiem uzyskania ministerialnej kontrasygnaty jego aktów. Wymóg ten powiązano z kwestią odpowiedzialności, zapisano bowiem, że współpodpisujący minister ponosi odpowiedzialność za akt królewski.

5. Holenderska konstytucja z 27 września 1815 r. ${ }^{16}$ nie wyrażała wprost zasady nieodpowiedzialności panującego (choć tę regułę uznać wypada za oczywistą), nie przewidziano też ograniczenia władcy zasadą współpodpisu. Regułę kontrasygnaty wprowadzono do ustawy zasadniczej w ramach nowelizacji dokonanej w 1840 r. ${ }^{17}$ Odtąd wszelkie królewskie dekrety miały być opatrzone współpodpisem właściwego szefa departamentu (art. 76), zaś kontrasygnujący minister miał podlegać odpowiedzialności prawnej (art. 77).

6. Ustrój Szwecji na długie lata określono w konstytucji z 6 czerwca 1809 r. ${ }^{18}$ Zagwarantowano nieodpowiedzialność i świętość osoby panującego Konungens Majestät skall hållas $i$ helgd och vördnad (§ 3).Władca mógł więc działać jedynie po uzyskaniu opinii Rady Państwowej (czyli rządu) lub podpisu jednego z czterech sekretarzy stanu. Każdy akt monarchy miał być podpisany przez właściwego ministra. Gdy ten uznał przedstawiony mu projekt za sprzeczny z konstytucją, powinien zgłosić pisemny protest do Rady, a gdy król obstawał przy żądaniu zatwierdzenia jego aktu, powinien odmówić kontrasygnaty i złożyć funkcję, zachowując dotychczasowe uposażenie (§ 8-9).

7. W ustawie zasadniczej uchwalonej przez norweską konstytuantę 17 maja 1814 r. ${ }^{19}$ zapisano, że osoba króla jest święta (Kongens Person er hellig), władca nie może być obwiniony ani oskarżony, zaś odpowiedzialność spoczywa na jego Radzie (§ 4). Wszystkie decyzje króla ${ }^{20}$ podlegały wymogowi kontrasygnaty ( $\$ 31$ i 32). Rozwiązanie przyjęte w konstytucji eidsvollskiej było dość oryginalne. Minister, do którego władca zwracał się o zatwierdzenie jego aktu, mógł złożyć formalny protest do protokołu posiedzeń Rady Państwowej. Złożenie takiego protestu zwalniało członka Rady z odpowiedzialności prawnej, nawet gdy następnie kontrasygnował akt królewski.

8. Pierwszą duńską konstytucję Fryderyk VII podpisał 5 czerwca 1849 r. ${ }^{21}$ Zadeklarowano w niej zasadę nieodpowiedzialności monarchy i świętości

1831. Herzien in 1893 en 1920-1921. La constitution belge de 1831. Revisée en 1893 et 1920-1921, Gent-Gand 1922; zob. też http://mjp.univ-perp.fr/constit/be1831.htm - stan na 1 maja $2013 \mathrm{r}$.

${ }^{16} \mathrm{http} / / /$ nl.wikisource.org/wiki/Grondwet_voor_het_Koningrijk_der_Nederlanden_(1815) - stan na 1 maja $2013 \mathrm{r}$.

$17 \mathrm{http} / / /$ nl.wikisource.org/wiki/Grondwet_voor_het_Koningrijk_der_Nederlanden_(1840) - stan na 1 maja $2013 \mathrm{r}$.

${ }^{18} \mathrm{http} / / /$ sv.wikisource.org/wiki/Regeringsform_1809 - stan na 1 maja $2013 \mathrm{r}$.

${ }^{19} \mathrm{http} / / /$ www.nb.no/baser/1814/17may.html - stan na 1 maja $2013 \mathrm{r}$.

${ }^{20}$ Po nowelizacji konstytucji przeprowadzonej po zawarciu unii ze Szwecją również wicekróla lub namiestnika.

${ }^{21} \mathrm{http}: / /$ danmarkshistorien.dk/leksikon-og-kilder/vis/materiale/danmarks-riges-grundlov-af-5juni-1849-junigrundloven/\#indhold3 - stan na 1 maja $2013 \mathrm{r}$. 
jego osoby (Kongen er ansvarsfri; hans Person er hellig og ukrcenkelig $\S 18)$. Jednocześnie wskazano, że odpowiedzialność ponoszą ministrowie (§ 18). Zgodnie z $\S 19$ podpis władcy pod aktami ustawodawczymi i aktami władzy wykonawczej był skuteczny tylko gdy towarzyszył mu podpis ministra. Powtórzono w tym miejscu zasadę ministerialnej odpowiedzialności minister, który kontrasygnował akt władcy, miał być odpowiedzialny za podjęcie decyzji.

W kolejnej duńskiej ustawie zasadniczej z 28 lipca 1866 r. $^{22}$ (wypracowanej przez oba istniejące wówczas parlamenty - Rigsdag i Rigsraad i nazwanej nowelizacją konstytucji z 1849 r.) nieodpowiedzialność władcy została zadeklarowana $\mathrm{w} \S 12$. Jednocześnie wskazano, że określoną przez prawo odpowiedzialność ponosić będą ministrowie. Z § 13 zd. 4 wynikało, że odpowiadali oni w szczególności za złożenie współpodpisu - w tym zakresie zachowano więc regulację z 1849 r.

9. Zgodnie z konstytucją Kadyksu z 19 marca 1812 r. ${ }^{23}$ osoba panującego była święta, nietykalna i nie podlegała odpowiedzialności (art. 168), a z art. 225 wynikała zasada, że wszelkie akty władcy wymagały kontrasygnaty ze strony sekretarza stanu, bez której nie były skuteczne.

W art. 67 hiszpańskiej konstytucji z 1 czerwca 1869 r. ${ }^{24}$ zapisano, że król jest nieodpowiedzialny, a odpowiadać mieli ministrowie (art. 67). Wszelkie akty władcy objęte były obowiązkiem uzyskania ministerialnej kontrasygnaty (art. 87).

10. W art. 127 zd. 1 pierwszej portugalskiej konstytucji z 23 września 1822 r. $^{25}$ zapisano, że osoba króla jest nietykalna i władca nie podlega żadnej odpowiedzialności. Dla ważności dekretów i innych aktów królewskich konieczne było podpisanie ich przez właściwego sekretarza stanu (art. 161).

Według konstytucji Portugalii z 4 kwietnia $1838 \mathrm{r}^{26}$ król był nietykalny i nieodpowiedzialny (art. 85), a wszystkie jego akty wymagały ministerialnej kontrasygnaty (art. 115).

11. Grecka konstytucja z 1 (13) stycznia $1827 \mathrm{r}^{27}$ kierowanie egzekutywą powierzała prezydentowi (jeden z art. 41, 102, 105, 126), wybranemu przez Senat (art. 120). Z art. 106 i 127 wynikał wymóg kontrasygnowania aktów prezydenckich przez jednego $\mathrm{z}$ sekretarzy stanu. Istotne zmiany przyniosła ustawa zasadnicza z 18 (30) marca 1844 r. ${ }^{28}$, która czyniła z Grecji monar-

${ }^{22} \mathrm{http}: / /$ thomasthorsen.dk/pol/1866-constitution.php - stan na 1 maja $2013 \mathrm{r}$.

${ }^{23} \mathrm{http}: / / \mathrm{bib} . c e r v a n t e s v i r t u a l . c o m / s e r v l e t / S i r v e O b r a s / 02438387547132507754491 / \mathrm{p} 0000001 . \mathrm{htm}$ \#I_0 - stan na 19 maja 2013 r.

${ }^{24} \mathrm{http} / / /$ bib.cervantesvirtual.com/servlet/SirveObras/79140511430137617422202/p0000001.htm \#I_1 - stan na 19 lipca 2012 r.

${ }^{25} \mathrm{http}: / /$ debates.parlamento.pt/Constituicoes_PDF/CRP-1822.pdf - stan na 1 maja $2013 \mathrm{r}$.

${ }^{26} \mathrm{http}: / /$ debates.parlamento.pt/Constituicoes_PDF/CRP-1838.pdf - stan na 1 maja $2013 \mathrm{r}$.

${ }^{27} \mathrm{http} / / / \mathrm{mjp}$.univ-perp.fr/constit/gr1827.htm - stan na 1 maja $2013 \mathrm{r}$.

${ }^{28} \mathrm{http} / / /$ mjp.univ-perp.fr/constit/gr1844.htm - stan na 1 maja $2013 \mathrm{r}$. 
chię. Zgodnie z art. 22 osoba króla była nietykalna, a odpowiedzialni mieli być ministrowie, którzy - zgodnie z art. 23 - kontrasygnowali akty królewskie. Interesujący był art. 23 ust. 2 ustawy zasadniczej, w którym prawodawca odniósł się do sytuacji, w której ministrowie mieliby złożyć podpis pod dekretem w sprawie ich odwołania. W przypadku odmowy współpodpisania takiego aktu zatwierdzić mógł go nowy premier powołany przez władcę. Również w greckiej konstytucji z 17 (29) października 1864 r. ${ }^{29}$ zadeklarowano zasadę nieodpowiedzialności monarchy, a jego akty mieli kontrasygnować odpowiedzialni ministrowie (art. 29-30).

12. W bułgarskiej ustawie zasadniczej z 16 (28) kwietnia 1879 r. ${ }^{30}$ zapisano, że osoba władcy jest święta i nietykalna (art. 8), a akty książęce objęte są ministerialną kontrasygnatą (art. 154).

13. Zgodnie z art. 82 rumuńskiej konstytucji z 1 (13) czerwca 1866 r. $^{31}$ władca był nieodpowiedzialny, a jego akty wymagały ministerialnej kontrasygnaty, przy czym minister miał podlegać odpowiedzialności ,przez sam fakt złożenia podpisu" (art. 92).

14. Obowiązek kontrasygnaty aktów panującego zapisany został również w art. 100 ust. 2 konstytucji Serbii z 29 czerwca (11 lipca) 1869 r. ${ }^{32}$ i korespondował z zasadą nieodpowiedzialności i nietykalności księcia wyrażoną $\mathrm{w}$ art. 3. Podobne reguły ustrojowe przyjęto w serbskiej konstytucji z 22 grudnia 1888 r. ${ }^{33}$ Król był nieodpowiedzialny (art. 40), a jego akty wymagały kontrasygnaty (art. 136). To samo wynikało z art. 11 ustawy zasadniczej z 6 kwietnia $1901 \mathrm{r}^{34} \mathrm{~W}$ tym ostatnim akcie odnajdujemy szczególną regulację zasady współpopodpisu. Z art. 15 wynikało, że dekret władcy o rozwiązaniu Skupsztyny wymagał zatwierdzenia przez wszystkich urzędujących ministrów.

15. W państwach wchodzących w skład Związku Niemieckiego ustrojodawcy konsekwentnie przyjmowali zasadę nieodpowiedzialności władców. Świętość i nietykalność osoby panującego zagwarantowano m.in.: w Królestwie Bawarii ( $\$ 1$ ust. 2 konstytucji z 26 maja 1818 r. ${ }^{35}$ ), Królestwie Saksonii (§ 4 konstytucji z 4 września 1831 r.), Królestwie Wirtembergii (§ 4 ust. 2 konstytucji z 25 sierpnia 1819 r.), Królestwie Hanoweru (§ 6 ust. 2 konstytucji z 26 września 1833 r.), Wielkim Księstwie Badenii ( 55 ust. 2 konstytucji z 22 sierpnia 1818 r.) oraz w Hesji ( 11 konstytucji z 5 stycznia 1831 r.). Prawna nieodpowiedzialność władców zazwyczaj powiązana była z obowiązkiem ministerialnej kontrasygnaty ich aktów. Zapisano to w $§ 108$ konstytu-

${ }^{29} \mathrm{http}: / /$ mjp.univ-perp.fr/constit/gr1864.htm - stan na 1 maja $2013 \mathrm{r}$.

${ }^{30} \mathrm{http}: / /$ mjp.univ-perp.fr/constit/bg1879.htm - stan na 1 maja $2013 \mathrm{r}$.

${ }^{31} \mathrm{http} / / / \mathrm{mjp}$.univ-perp.fr/constit/ro1866.htm - stan na 1 maja $2013 \mathrm{r}$.

${ }^{32} \mathrm{http}: / /$ mjp.univ-perp.fr/constit/rs1869.htm - stan na 2 czerwca $2013 \mathrm{r}$.

${ }^{33}$ Ibidem.

${ }^{34} \mathrm{http}: / /$ mjp.univ-perp.fr/constit/rs1901.htm - stan na 2 czerwca $2013 \mathrm{r}$.

${ }^{35}$ Wszystkie przywoływane konstytucje państw niemieckich dostępne są na stronie internetowej o adresie http://www.documentarchiv.de/nzjh.html - stan na 1 maja 2013 r. 
cji Hesji z 1831 r. (w którym podano, że kontrasygnujący jest osobiście odpowiedzialny za zgodność aktu z konstytucją i ustawami), § 43 konstytucji Saksonii z 1831 r. (kontrasygnujący odpowiada za zgodność aktu z ustawami i konstytucją, ale również za jego celowość) oraz w $§ 151$ ust. 1 konstytucji Hanoweru z $1833 \mathrm{r}$.

Zgodnie z art. 44 konstytucji Prus z 31 stycznia 1850 r. ${ }^{36}$ każdy akt rządowy króla wymagał dla ważności współpodpisu ministra, który „przejmował za niego odpowiedzialność".

Podobnie skonstruowany przepis - jako art. 17 - znalazł się w konstytucji II Rzeszy Niemieckiej z 18 stycznia $1871 \mathrm{r}^{37} \mathrm{i}$ wprowadzał wymóg kontrasygnaty rozporządzeń i dekretów cesarza przez kanclerza (,„przejmującego w ten sposób odpowiedzialność").

16. Również akty rządowe cesarza Austrii doby konstytucyjnej wymagały dla swej ważności kontrasygnaty odpowiedzialnego ministra, co wynikało z art. 1 ustawy z 25 lipca 1867 r. o odpowiedzialności ministrów dla królestw i krajów reprezentowanych w Radzie Państwa ${ }^{38}$.

\section{Nieopowiedzialność monarchy i kontrasygnata aktów władcy we włoskich konstytucjach okresu Risorgimento.}

1. Zanim w 1861 r. proklamowano zjednoczenie Włoch, na Półwyspie Apenińskim istniało szereg niepodległych państw, z których największymi były: Królestwo Sardynii, Królestwo Sycylii, Państwo Kościelne i Wielkie Księstwo Toskanii. W czasie Wiosny Ludów, przez Włochów zwanej Risorgimento, władcy tych krajów zmuszeni byli nadać ustawy zasadnicze, a rządzone przez nich państwa na kilkanaście miesięcy stały się monarchiami konstytucyjnymi.

2. Pierwszą z tych konstytucji ogłoszono 11 lutego 1848 r. w Królestwie Obojga Sycyliii ${ }^{39}$. W art. 63 zapisano, że osoba władcy jest święta i nietykalna, a król nie podlega odpowiedzialności jakiegokolwiek rodzaju. Zgodnie $\mathrm{z}$ art. 72 akty monarchy nie miały mocy bez współpodpisu ministra-sekretarza stanu, który miał być za ten akt wyłącznie odpowiedzialny (art. 72).

W art. 35 Statutu Fundamentalnego Królestwa Sycylii z 10 lipca 1848 r. ${ }^{40}$ zapisano, że osoba króla jest nietykalna. Żadnego z przyznanych przez konstytucję uprawnień panujący nie mógł wykonywać bez konsultacji z radą ministrów (art. 51) i żaden rozkaz władcy nie mógł być wykonany, jeśli nie był podpisany przez ministra (art. 52).

${ }^{36} \mathrm{http}: / /$ en.wikisource.org/wiki/Constitution_of_the_Kingdom_of_Prussia - stan na 12 czerwca $2013 \mathrm{r}$.

${ }^{37}$ Tekst w: M.J. Ptak, M. Kinstler, op. cit., s. 195-201.

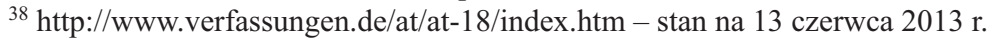

${ }^{39} \mathrm{http}: / /$ www.dircost.unito.it/cs/docs/sicilie1848.htm - stan na 1 maja $2013 \mathrm{r}$.

${ }^{40} \mathrm{http}: / /$ www.dircost.unito.it/cs/docs/sicilia184.htm - stan na 1 maja $2013 \mathrm{r}$. 
Na początku 1849 r. Ferdynand II podjął próbę ugodowego zakończenia rewolucji na Sycylii, jaką był akt konstytucyjny wydany w Gaecie 28 lutego ${ }^{41}$. W art. 6 zagwarantowano nietykalność (w tym nieodpowiedzialność) władcy. Na podstawie art. 21 akty władzy wykonawczej (czyli akty królewskie, albowiem zgodnie z art. 6 władza wykonawcza należała wyłącznie do króla) podlegały kontrasygnacie właściwego ministra.

3. W art. 12 Statutu Wielkiego Księstwa Toskanii z 15 lutego 1848 r. $^{42}$ przyjęto jako zasadę ustrojową, że osoba wielkiego księcia jest nietykalna i święta. Nie przewidziano kontrasygnaty aktów władcy.

\section{Regulacja odpowiedzialności monarchy i kontrasygnaty jego ak- tów w statucie albertyńskim.}

1. W marcu 1861 r. Wiktor Emanuel proklamował powstanie Królestwa Włoch. Pod względem formalnym nowa monarchia, stanowiąc kontynuację Królestwa Sardynii, przejęła jej system prawny, w szczególności konstytucję. Statut Fundamentalny Monarchii Sabaudzkiej (Statuto Fondamentale della Monarchia di Savoia ${ }^{43}$ ) został ogłoszony przez Karola Alberta 4 marca 1848 r. i w przeciwieństwie do innych ustaw zasadniczych ogłoszonych podczas $R i$ sorgimento nigdy nie został odwołany.

W większości postanowienia konstytucji były na tyle ogólne, że ewolucja ustroju mogła następować bez zmiany litery prawa ${ }^{44}$.

2. Monarcha był najwyższym zwierzchnikiem państwa (Capo Supremo dello Stato) i wyłącznie do niego należała władza wykonawcza. W art. 4 zapisano zasadę nieodpowiedzialności władcy - „osoba króla jest święta i nietykalna" (La persona del Re è Sacra e inviolabile).

3. Art. 67 statuujący ogólną zasadę prawnej odpowiedzialności ministrów oraz kontrasygnaty ministerialnej brzmiał nastepująco: I Ministri sono responsabili. Le leggi e gli atti del Governo non hanno vigore se non sono muniti d'una firma di un Ministro ${ }^{45}$. Zdanie pierwsze nie przysparza trudności interpretacyjnych. Bez wątpienia chodziło o prawną odpowiedzialność ministrów.

${ }^{41}$ Akt datowany jest na 28 lutego 1849 r., taką datę podają autorzy włoscy - G. Libertini, G. Paladino, op. cit., s. 699, jednak w polskim piśmiennictwie odnajdujemy wskazanie daty o sześć dni wcześniejszej (zapewne w wyniku omyłki) - J.A. Gierowski, op. cit., s. 438. Tekst - zob.: http:// www.dircost.unito.it/cs/docs/gaeta-sici.htm - stan na 1 maja $2013 \mathrm{r}$.

${ }^{42} \mathrm{http}: / /$ www.dircost.unito.it/cs/docs/Granduc_tosc1848.htm - stan na 1 maja $2013 \mathrm{r}$.

${ }^{43} \mathrm{http}: / /$ www.dircost.unito.it/cs/docs/albertino1848.htm - stan na 1 maja $2013 \mathrm{r}$.

${ }^{44}$ M. Rakowski, Prawo wyborcze do włoskiej Izby Deputowanych w latach 1861-1923, Warszawa 2004, s. 8-9; zob. też G. Arcoleo, Diritto costituzionale. Dottrina e storia, Napoli 1907, s. 239; I. Tambaro, Il diritto costituzionale italiano, Milano 1909, s. 244.

${ }^{45}$ Ministrowie sa odpowiedzialni. Ustawy oraz akty Rzadu nie maja mocy, jeśli nie sq opatrzone podpisem Ministra. Użyty przez prawodawcę przymiotnik munito oznacza: uzbrojony, ufortyfikowany, wyposażony, zaopatrzony, uzbrojony - H. Cieśla, E. Jamrozik, J. Sikora Penazzi, Wielki stownik włosko-polski, t. II, Warszawa 2002, s. 614. Czasownik munire to zaopatrzyć, wyposażyć, udzielać, uzbroić - M. Grelewicz-La Mela, B. Nutto, Słownik prawniczy włosko-polski. Dizionario 
Ponosili ją na zasadzie impeachment - oskarżenie wnosiła Izba Deputowanych (art. 47), a orzekanie należało do Senatu, który stawał się Najwyższym Trybunałem Sprawiedliwości - Alta Corte di Giustizia (art. 36).

Więcej problemów rodzi treść zdania drugiego art. 67. Bez wątpienia dotyczy on kontrasygnaty, bowiem ministerialny podpis jest konieczny dla „mocy”, czyli ważności aktu. Powstaje jednak pytanie, jakie akty podlegały zasadzie współpodpisu. Co ciekawe, w analizowanym przepisie nie wspomniano wprost o aktach wydanych przez króla. Mowa jest po pierwsze o ustawach (choć uznać wypada za zaskakującą normę uzależniającą ważność ustawy od woli ministra), a po drugie - o aktach wydawanych przez governo, co odruchowo, ale naszym zdaniem błędnie, można tłumaczyć jako „rząd”46. Włoski wyraz governo ma znacznie więcej znaczeń, wśród nich: „rządzenie”, „kierowanie”, „rządy”, „gabinet”, „zarząd”, „władze”, „państwo”47. W żadnym z pozostałych przepisów Statutu Albertyńskiego termin ten nie został użyty w odniesieniu do gabinetu, co więcej - w konstytucji mowa jest wyłącznie o ministrach, a nie o kolegium, które mieliby tworzyć. Za to w art. 2 ustawy zasadniczej czytamy, że państwo jest rządzone przez Governo Monarchico e Rappresentativo, czyli governo oznacza w tym przypadku ,władze”. Zatem w art. 67 mowa jest o aktach egzekutywy, a ponieważ z art. 5 zd. 1 wynika, że władza wykonawcza należy w całości do monarchy: obowiązek uzyskania współpodpisu należy odnosić do aktów wydawanych przez władcę.

W starszej włoskiej literaturze przedmiotu nie natrafiliśmy na ślad wskazujący, by art. 67 budził wątpliwości interpretacyjne. W szczególności żaden $\mathrm{z}$ autorów nie usiłował wykazać, że przepis ten nie odnosi się do aktów wydawanych przez króla. Przedstawioną wyżej wykładnię art. 67 uznawano za tak oczywistą, że nie dostrzegano nawet potrzeby wskazania, z czego wynika przekonanie, że kontrasygnatą objęte są działania władcy.

\section{Nieodpowiedzialność króla w piśmiennictwie włoskim.}

1. W dziewiętnastowiecznym piśmiennictwie włoskim zasadę nieodpowiedzialności władcy traktowano jako ustrojowy aksjomat i poszukiwano uzasadnienia tej reguły ustrojowej - nieodpowiedzialność panującego postrzegano bowiem jako oczywistą cechę monarchii konstytucyjnej.

2. W 1885 r. Aprile Di Cimia wskazywał na najważniejsze cechy głowy państwa w monarchii: l'ereditá, l'irresposabilitá, l'inviolabilitá - czyli dziedziczność, nieodpowiedzialność i nietykalność ${ }^{48}$. Trzynaście lat wcześniej

giuridico italiano-polaco, Warszawa 2003, s. 282. Naszym zdaniem w badanym przepisie muniti tłumaczyć należy jako „opatrzone”.

${ }^{46}$ Jak czyni to A. Rakowska, op. cit., s. 266.

${ }^{47}$ H. Cieśla, E. Jamrozik, J. Sikora Penazzi, op. cit., t. II, s. 168.

${ }^{48}$ A. Di Cimia, Il capo dello stato nei governi costituzionali, Torino 1885, s. 43. Inviolabilitá oznacza: nienaruszalność, świętość, nietykalność - H. Cieśla, E. Jamrozik, J. Sikora Penazzi, Wiel- 
Giusto Emanuele Garelli przekonywał, że nietykalność panującego jest logiczną konsekwencją wykonywanej przezeń misji i stanowi „kamień węgielny budowli, jaką jest monarchia reprezentacyjna". Tłumaczył, że władca nie może ponosić odpowiedzialności, gdyż jest symbolem suwerenności, w którym urzeczywistnia się ta koncepcja teoretyczna. Zdaniem Garelliego jedynie nieponoszący odpowiedzialności król może stanowić przeciwwagę dla innych organów niezależnych - Senatu, Izby Deputowanych oraz sądów; wolność i nietykalność monarchy postrzegał jako gwarancję dla narodu ${ }^{49}$. Również zdaniem Rodolfo Calamandrei istota monarchii polega na tym, że - jak w Anglii - król nie może czynić źle, czyli nie może zostać oskarżony, sądzony ani ukarany, jest nieodpowiedzialny i nietykalny. To odróżnia monarchię od republiki, w której prezydent może odpowiadać prawnie ${ }^{50}$.

Podobnie rzecz ujmowali Giuseppe Saredo i Pietro Chimenti. Pierwszy z nich (krótko po zjednoczeniu Italii) wskazywał, że fundamentalną zasadą monarchii konstytucyjnej jest bezosobowość władcy (jako „najwyższego i bezstronnego reprezentanta suwerenności”), który jest ,zamknięty w sanktuarium swojej bezosobowości, nie czyni niczego, ale wszystkiemu przewodniczy". Autor ten dostrzegał jednak, że jest to tylko konstrukcja abstrakcyjna ${ }^{51}$. Z kolei Chimenti - już po I wojnie światowej - przekonywał, że urząd głowy państwa reprezentuje ciągłość życia prawnego państwa ${ }^{52}$. Korona jako instytucja prawa publicznego żyje życiem własnym i odrębnym reprezentując zasadę stabilności i kontynuacji bytu państwa. Inviolabilitá głowy państwa - jak pisał - oznacza jej nieodpowiedzialność na gruncie ustawodawstwa karnego, przed sądami i opinią publiczną ${ }^{53}$.

3. Warto ustalić rodzaj odpowiedzialności, co do której ustrojodawca odnosił gwarancję nieodpowiedzialności władcy. Z istoty godności królewskiej wynikało, że panujący nie ponosił odpowiedzialności politycznej - nie mógł być odwołany przez parlament ani przez naród. Zresztą w połowie XIX w., gdy ogłoszono sardyński Statut, możliwości odwołania nie nazywano jeszcze „pociągnięciem do odpowiedzialności”. Pojęcie odpowiedzialności odnosiło się jedynie do odpowiedzialności prawnej, czyli wiązane było z negatywnymi konsekwencjami naruszenia prawa przez osobę pełniącą funkcję publiczną. Badany art. 4 Statutu miał więc wyrażać zasadę, że władcy nie można

ki słownik włosko-polski, t. II, Warszawa 2002, s. 402. Irresposabilitá - to niepodleganie odpowiedzialności, ale także nieodpowiedzialność jako lekkomyślność - ibidem, s. 414. Irresposabilitá to także niepoczytalność - M. Grelewicz-La Mela, B. Nutto, op. cit., s. 251.

${ }^{49}$ G.E. Garelli, Il diritto costituzionale italiano, Torino 1872, s. 214-215.

${ }^{50}$ R. Calamandrei, Monarchia e repubblica rapresentative, [w:] A. Brunialti (red.), Scelta collezione delle piu importanti opere moderne italiane e straniere di scienze politiche, t. 2. Torino 1886, s. 1215.

${ }^{51}$ G. Saredo, Principii di diritto costituzionale, t. 2, Parma 1862, s. 263-266.

${ }^{52}$ P. Chimenti, Manuale di diritto costituzionale, Roma 1920, s. 474.

${ }^{53}$ Ibidem, s. 318-319. 
pociągnąć do jakiejkolwiek odpowiedzialności za naruszenie prawa; jego nieodwoływalność (bez naruszenia prawa) była oczywista i wynikała z istoty monarchii.

W piśmiennictwie natrafiamy jednak na opinię, że w pewnym sensie nawet król ponosi odpowiedzialność. W interesujący sposób rzecz przedstawiał Michele Solimene, który wskazywał, że nieodpowiedzialny prawnie władca - jak każdy człowiek - ponosi odpowiedzialność moralną przed Bogiem i opinią publiczną ${ }^{54}$. Nie mamy tu z pewnością do czynienia z rozumowaniem contra legem, a jedynie z dostrzeżeniem wieloznaczności i niedookreśloności pojęcia odpowiedzialności (które używane bywa również przy określeniu zakresu zadań i kompetencji organu).

4. Należy przyjrzeć się również użytemu przez ustrojodawcę stwierdzeniu, że osoba władcy jest ,święta”. Z pewnością nie chodzi tu o ,świętość" na gruncie wierzeń religijnych, w szczególności nie zadeklarowano, by sardyński, a później włoski, monarcha był świętym Kościoła katolickiego. Chimenti tłumaczył, że konstytucyjne określenie świętości panującego nie ma znaczenia prawnego, a jedynie aspekt historyczny i symboliczny. Osobom wierzącym przypominać ma o dawnej funkcji króla jako pomazańca bożego, a wszystkim obywatelom o tym, że głowa państwa jest święta w tym znaczeniu, w jakim święty jest „majestat narodu reprezentowanego przez władcę"55.

5. Włoscy konstytucjonaliści i mężowie stanu doskonale zdawali sobie sprawę, że przyjęcie zasady nieodpowiedzialności prawnej panującego pociąga za sobą odsunięcie go od faktycznego decydowania w sprawach publicznych. Solimene już w roku wydania Statutu wskazywał, że w ówczesnej Anglii oraz we Francji za czasów Ludwika Filipa obowiązywała zasada, że „król panuje, ale nie rządzi”" ${ }^{\prime 5}$. Podobnie kilkanaście lat później rzecz przedstawiał Saredo, według którego nietykalny i nieodpowiedzialny monarcha nie może działać samodzielnie, gdyż działanie rodzi odpowiedzialność, więc „panuje, ale nie rządzi”. Przypominał też (choć bez podania przykładów), że w przeszłości byli władcy, którzy ponosili za swą działalność odpowiedzialność ${ }^{57}$. Teraz król miał panować, ale nie sprawować rządów. Próbowano doszukać się dobrych dla władcy stron takiego stanu - na początku zeszłego stulecia Ferracciu tłumaczył, że wraz ze zmniejszeniem się politycznej roli monarchy wzrosła jego ,siła moralna i społeczna" 58 .

Pozbawienie władcy możliwości samodzielnego działania wynikało jednak nie tyle z zagwarantowania jego nieodpowiedzialności, ile przede wszyst-

${ }^{54}$ M. Solimene, Corso di diritto costituzionale e comento sulla costituzione, Napoli 1848, s. 130.

${ }^{55}$ P. Chimenti, op. cit., s. 318.

${ }^{56}$ M. Solimene, op. cit., s. 133.

${ }^{57}$ G. Saredo, op. cit., s. 263-267.

${ }^{58}$ A. Ferracciu, Contributo allo studio della funzione regia nel governo di gabinetto, Milano 1902, s. 133. 
kim z wprowadzenia ministerialnej kontrasygnaty jego aktów. Dostrzegał to Garelli, zdaniem którego z zasady nieodpowiedzialności króla i wymogu współpodpisu wynikało, że król konstytucyjny jest nieosobowy i pasywny (impersonale e passivo) - czyli panuje i nie rządzi. Dodawał jednak, iż nie można zapominać, że to władca wybiera ministrów ${ }^{59}$. Było to o tyle nietrafne, że już wówczas włoski król musiał podążać za wskazaniem parlamentarnej większości ${ }^{60}$.

\section{Kontrasygnata w piśmiennictwie włoskim.}

1. Włoscy autorzy często wiązali zasadę nieodpowiedzialności władcy z prawną odpowiedzialnością ministrów. Solimene twierdził, że święty, nietykalny, wolny od wszelkiej odpowiedzialności król nie odpowiada za akty wydawane w jego imieniu, zaś odpowiedzialność ponoszą ministrowie za akty sprzeczne ze statutem lub systemem rządów ${ }^{61}$. Nietykalny monarcha - jak pisał Garelli - musi mieć funkcjonariuszy, którzy odpowiadają za niego, może działać tylko przez ministrów, którzy są odpowiedzialni. Odpowiedzialność ministrów miała więc być koniecznym warunkiem każdego aktu królewskiego dotyczącego spraw publicznych ${ }^{62}$. Akt władcy winien podpisać minister właściwy w danych sprawach albo premier, gdy sprawy należały do właściwości wszystkich lub większości ministrów ${ }^{63}$.

Saredo $^{64}$, Chimenti ${ }^{65}$, Contuzzi ${ }^{66}$, Calmandrei ${ }^{67}$, Brunialti ${ }^{68}$ zwracali uwagę na ścisły związek między nieodpowiedzialnością panującego a odpowiedzialnością ministrów. Saredo ${ }^{69}$ oraz Orlando ${ }^{70}$ wskazywali, że dzięki kontrasygnacie odpowiedzialność ministrów pokrywa akty monarchy. Pierwszy z nich prezentował też dość oryginalny pogląd, że współpodpis ministra czyni go ,poręczycielem cywilnym i politycznym"71. Wśród wypowiedzi na temat kontrasygnaty warto dostrzec poglądy Vacchelliego. Jego zdaniem nieodpo-

${ }^{59}$ G.E. Garelli, op. cit., s. 219-220.

${ }^{60}$ M. Rakowski, System parlamentarno-gabinetowy w Królestwie Sardynii, „Przegląd Prawa Publicznego" nr 3/2013, s. 79-99.

${ }^{61}$ M. Solimene, op. cit., s. 136.

${ }^{62}$ G.E. Garelli, op. cit., s. 216-217. W pewnym oderwaniu od obowiązujących już wówczas we Włoszech zwyczajów konstytucyjnych Garelli wskazywał, że władca ma swobodę w wyborze ministrów, których darzy zaufaniem.

${ }^{63}$ M. Solimene, op. cit., s. 131.

${ }^{64}$ Korona jest nieodpowiedzialna, a odpowiadają ministrowie, którzy kontrasygnują akty G. Saredo, op. cit., t. 2, s. 33, 42-43.

${ }^{65}$ P. Chimenti, op. cit., s. 446, 454, 474-475.

${ }^{66}$ Ibidem, s. 482.

${ }^{67}$ Odpowiedzialność ministrów jest skorelowana z nieodpowiedzialnością panującego - R. Calamandrei, op. cit., s. 1216.

${ }^{68}$ A. Brunialti, Guida allo studio del diritto costituzionale, Torino 1882, s. 245.

${ }^{69}$ G. Saredo, op. cit., s. 286-287.

${ }^{70}$ V.E. Orlando, Principii di diritto costituzionale, Firenze 1905, s. 238.

${ }^{71}$ G. Saredo, op. cit., s. 265. 
wiedzialność głowy państwa nie wywodzi się z reguły, że ministrowie są odpowiedzialni za to, co czyni władca, ale z zasady, że król nie może czynić źle, zaś jego wola jest wolą instytucjonalną, a nie wyrazem osobistych możliwości. Należy więc - jak pisał - dedukować, że odpowiedzialność ministra zastępuje odpowiedzialność głowy państwa ${ }^{72}$.

2. Wynikający ze Statutu Albertyńskiego wymóg kontrasygnaty aktów władcy oznaczał przyjęcie zasady niesamodzielności panującego, choć w art. 5 konstytucji zadeklarowano, że jedynie do króla należy władza wykonawcza. Zatem podmiot mający pełnię tej władzy miałby być jednocześnie pozbawiony możliwości jej wykonywania. Jak pisał Mosca - Statut przyznawał władcy szerokie uprawnienia, ale ten mógł je wykonywać jedynie współdziałając z ministrami ${ }^{73}$. Już Saredo (w 1862 r.) tłumaczył, że statutowego sformułowania o pełni władzy wykonawczej monarchy nie można interpretować dosłownie, gdyż w takim przypadku władca działałby na swoje ryzyko. Przekonywał, że król jest w takim samym stopniu szefem egzekutywy, jak legislatywy czy sądownictwa ${ }^{74}$. Dla Erico Presuttiego stwierdzenie, że tylko król sprawuje władzę wykonawczą, oznacza jedynie, że inne organy nie mogą przejmować funkcji egzekutywy ${ }^{75}$. W rzeczywistości - jak trafnie zauważał Gaetano Mosca - już krótko po wydaniu Statutu polityka zagraniczna, władza wykonawcza, sądownictwo, wojsko należały do ludzi formalnie wybranych przez władcę, ale w rzeczywistości wskazanych przez izbę obieralną ${ }^{76}$. Znacznie wcześniej dostrzegał to Saredo, który także zwracał uwagę, że ministrowie są co prawda powoływani przez króla, ale pochodzą z większości parlamentarnej, czyli od większości narodu. Król - jako instytucja, a nie osoba - podąża za ich wskazaniami ${ }^{77}$. Podobnie istotę kontrasygnaty postrzegał Ludovico Casanova, dla którego królewskie akty kontrasygnują ministrowie absolutnie zależni od izb ${ }^{78}$.

3. W dawnej włoskiej literaturze przedmiotu odnajdujemy różne podejścia do istoty odpowiedzialności ministra kontrasygnującego akt monarchy. W niektórych pracach czytamy, że w takim przypadku współpodpisujący urzędnik odpowiada ,za akt władcy”, czyli - w zasadzie - za cudzy czyn. W innych odnajdujemy ujęcie odmienne - minister miałby odpowiadać za czyn własny, to jest za złożenie podpisu pod wadliwym aktem.

${ }^{72}$ G. Vacchelli, op. cit., s. 33 .

${ }^{73}$ G. Mosca, Appunti di diritto costituzionale, Milano 1912, s. 72-73; zob. też idem, Teorica..., s. $157-161$.

${ }^{74}$ G. Saredo, op. cit., s. 286-287.

${ }^{75}$ E. Presutti, Diritto costituzionale, Napoli 1915, s. 312.

${ }^{76}$ G. Mosca, Teorica dei governi e governo parlamentare. Studi storici i sociali, Milano 1923, s. 158 .

${ }^{77}$ G. Saredo, op. cit., s. 265.

${ }^{78}$ L. Casanova, Del diritto costituzionale lezioni, Firenze 1875, s. 81. 
Reprezentantem pierwszej teorii był Solimene, który podawał, że kontrasygnujący ministrowie odpowiadają za akty władcy ${ }^{79}$.

Dominowało jednak ujęcie, zgodnie z którym minister odpowiada za czyny własne, a nie cudze, czyli królewskie. Calmanderi przekonywał, że skoro król nie odpowiada, to musi być ktoś kto odpowiada za niego (per lui) i wskazywał, że we wszystkich monarchiach reprezentacyjnych akty króla są legalne, wykonywalne wówczas, gdy są podpisane przez ministra. Wyjaśniał jednak, że stwierdzenie, iż ministrowie odpowiadają „za króla” oznacza, że ponoszą negatywne konsekwencje tego, iż swoim działaniem zaakceptowali błąd królewski, czyli za to, że nie odmówili złożenia podpisu ${ }^{80}$. Podobnie rzecz ujmował Contuzzi, dla którego nie jest tak, że ministrowie odpowiadają za cudze, czyli królewskie działania, ale za czyny własne - za to, że udzielili złych rad albo pełniąc urząd, akceptowali działania władcy, kontrasygnując jego akty ${ }^{81}$.

4. We włoskim piśmiennictwie poszukiwano również odpowiedzi na pytanie, czy istotnie wszystkie akty monarchy objęte są wymogiem współpodpisu. Calmanderi podawał (choć tak mało jednoznacznie, że nie mamy pewności, czy odnosił to do Italii, czy też formułował postulaty de lege ferenda), że są sprawy, w których król działa bez współdziałania ministra. Miało do nich należeć rozwiązanie izby niższej, powoływanie nowych senatorów, sankcjonowanie ustaw, skorzystanie z prawa łaski, zwołanie i odroczenie parlamentu oraz dowodzenie siłami zbrojnymi ${ }^{82}$.

Również Vittorio Emanuele Orlando poszukiwał odpowiedzi na pytanie, czy wszystkie akty króla objęte są zasadą współpodpisu. Podawał, że tzw. szkoła francuska wyróżnia uprawnienia panującego o charakterze osobistym (diritti maiestatici), których nie dotyczy odpowiedzialność (czyli kontrasygnata) ministrów. Należy do nich dowodzenie siłami zbrojnymi, powoływanie ministrów, rozwiązanie izby obieralnej oraz prawo łaski. Jednak zdaniem Orlando była to teoria nie do zaakceptowania, opierająca się na fałszywym założeniu, że istnieją osobiste czynności króla konstytucyjnego ${ }^{83}$.

W praktyce kontrasygnaty wymagały wszelkie akty władcy, nawet dekret o powołaniu nowego prezydenta ministrów. Miał być on podpisany przez odwołanego premiera ${ }^{84}$. Włoscy autorzy zdawali się nie dostrzegać możliwych problemów z odmową złożenia podpisu, a przede wszystkim nie natrafiliśmy na wyjaśnienie, jaką wartość miał mieć podpis obywatela, który premierem

${ }^{79}$ M. Solimene, op. cit., s. 131.

${ }^{80}$ R. Calamandrei, op. cit., s. 1216.

${ }^{81}$ F.P. Contuzzi, op. cit., s. 483.

${ }^{82}$ R. Calamandrei, op. cit., s. 1217. Z kolei Vacchelli wskazywał, że uprawnienia głowy państwa można podzielić na prerogative i poteri ministeriali - G. Vacchelli, La responsabilitá ministeriale, Cremona 1896, s. 26-32.

${ }^{83}$ V.E. Orlando, Principii di diritto costituzionale, Firenze 1905, s. 238.

${ }^{84}$ F.P. Contuzzi, op. cit., s. 471. 
już nie był. Zasady tej bronił Orlando, który zastrzeżenia wobec konstrasygnowania nominacji ministerialnych przez ministrów ustępujących traktował jako problem pozorny. Niejasno thumaczył, że należy odróżnić stronę formalną od materialnej takiego aktu, zgodnie z którą odpowiadają ci urzędnicy, którzy akt kontrasygnowali ${ }^{85}$.

Nie dla wszystkich włoskich autorów kontrasygnata była ważną instytucją ustrojową. Na przykład Livio Minguzzi, obszernie opisując kształtowanie się angielskiego systemu parlamentarno-gabinetowego, nie wspominał o zasadzie współpodpisu ${ }^{86}$.

VIII. Uwagi końcowe. Przyjęcie przez sardyńskiego ustrojodawcę zasady nieodpowiedzialności prawnej króla nie powinno zaskakiwać. Trzeba bowiem w świetle dziewiętnastowiecznych konstytucji uznać, że była ona już wpisana w istotę monarchii konstytucyjnej. Natomiast wymóg kontrasygnaty aktów panującego nie był tak oczywisty ${ }^{87}$, choć wprowadzano go często. Zazwyczaj postrzegano go jako konsekwencję zasady, że władca nie odpowiada za naruszenie prawa.

Rozwiązanie przyjęte w Statucie Albertyńskim można uznać za szczególne dlatego, że w art. 67 włoskiej konstytucji zabrakło wyraźnego odniesienia do działań króla. Mimo to treść przepisu nie budziła wątpliwości interpretacyjnych, a włoscy autorzy zgodnie wskazywali, że istniał wynikający z konstytucji obowiązek kontrasygnaty aktów monarchy, którego istnienie powszechnie uzasadniano obowiązywaniem reguły nieodpowiedzialności władcy.

${ }^{85}$ V.E. Orlando, op. cit., s. 239.

${ }^{86}$ L. Minguzzi, Governo di gabinetto e governo prezidenziale. Studio, Bologna 1886, s. 11-60.

${ }^{87}$ Nie istniał bowiem w II Cesarstwie francuskim, w Holandii przed 1840 r. oraz w Wielkim Księstwie Toskanii. 